\title{
PILIHAN JUDUL TESIS \\ (Kajian Deskripsi Tesis Pada Universitas XYZ Di Jakarta) ${ }^{1}$ \\ SUPARMAN IBRAHIM ABDULLAH \\ Fakultas Ekonomi Universitas Tarumanegara \& \\ Program Pascasarjana Universitas Indraprasta PGRI \\ HERU SRIYONO \\ Program Studi Bimbingan Konseling \& \\ Program Pascasarjana Universitas Indraprasta PGRI
}

SARA SAHRAZAD

Program Studi Bimbingan Konseling

Universitas Indraprasta PGRI

\begin{abstract}
Abstrak. Penelitian ini membahas beda antara skripsi, tesis, dan disertasi menurut berbagai sumber. Kemudian bagaimana menentukan judul yang baik, utamanya untuk judul tesis. Selanjutnya berdasarkan 1052 judul sebagai sampel di suatu program pascasarjana XYZ di Jakarta dikaji dengan metode deskriptif menunjukkan temuan kecenderungan kata awal yang digunakan, kemudian variabel dependen serta variabel independen yang di pergunakan. Disamping itu ada kecenderungan metodologi yang kurang bervariasi, dan adanya dugaan baru adanya kesalahan turunan secara sekuensial. Masih terdapat adanya plagiat yang relative tipis yang ditandai adanya kutipan yang terlupakan menuliskan kembali sumbernya pada daftar pustaka. Namun dinilai semuanya memenuhi bobot persyaratan tesis sebagai karya ilmiah. Berdasarkan temuan sementara dilakukan beberapa saran perbaikan dalam rangka peningkatan mutu isi penelitian pada tesis diatas.
\end{abstract}

Kata Kunci: kajian deskriptif, tesis, disertasi, plagiat

Abstract. This study discusses the difference between thesis and dissertation according to various sources. Then how to determine a good title, especially for a thesis title. Furthermore, based on a sample of 1052 titles in a graduate program in Jakarta XYZ studied with methods of descriptive findings indicate that the initial tendency to use the word, then the dependent variable and the independent variables are in use. Besides, there is a tendency that is less varied methodologies, and new allegations of an error derived sequentially. There are still relatively thin presence of plagiarism that marked the memorable quote rewrite its source in the bibliography. However, they all meet the weight requirements assessed as scientific papers thesis. Based on the interim findings made several suggestions for improvement in order to improve the quality of the content of the research on the above thesis.

Keywords: descriptive studies, thesis, dissertation, plagiarism

\footnotetext{
${ }^{1}$ Makalah disajikan pada sesi parallel Seminar Hasil Penelitian dan Abdimas. Meningkatkan Kualitas Pembelajaran Berdasarkan Hasil Riset. LPPM Universitas Indraprsta PGRI. Jakarta 14 Desember 2013.
} 


\section{PENDAHULUAN}

Dalam rancangan peraturan pemerintah tentang Pendidikan dan Kebudayaan Republik Indonesia Tentang Standar Nasional Pendidikan Tinggi (SNPT) Kementerian Pendidikan dan Kebudayaan Direktorat Jenderal Pendidikan Tinggi Dan Badan Standar Nasional Pendidikan 2013, menyebutkan penjelasan tentang tiga jenjang ialah strata satu (Sarjana), strata dua (Magister), dan strata tiga (Doktor) harus memenuhi standar kompetensi yang mencakup aspek: a. sikap dan tata nilai; b.penguasaan pengetahuan/ keilmuan; c. keterampilan kerja umum; dan d. keterampilan kerja khusus.

Selanjutnya, dalam penulisan karya ilmiah setiap jenjang pendidikan S1, S2, dan S3 dituntut membuat laporan karya ilmiah dengan kriteria tertentu. Pada prinsipnya strata satu dituntut dapat melaporkan kajian ilmu pengeahuan atau teknologi. Strata dua dituntut mengembangkan ilmu pengetahuan dan atau teknologi. Strata tiga dituntut menemukan atau menciptakan ilmu pengetahuan atau teknlogi.

Program sarjana mampu: mengkaji pengetahuan dan atau teknologi di bidang keahliannya berdasarkan kaidah keilmuan, atau menghasilkan karya desain/seni beserta deskripsinya berdasarkan kaidah atau metoda rancangan baku, yang disusun dalam bentuk skripsi atau laporan tugas akhir. Program magister mampu: mengembangkan ilmu pengetahuan dan/atau teknologi di bidang keahliannya melalui penelitian ilmiah, atau menghasilkan karya desain/seni beserta konsep kajian yang didasarkan pada kaidah desain/seni, yang disusun dalam bentuk tesis. Program doktor mampu: menemukan atau menciptakan ilmu pengetahuan dan/atau teknologi di bidang keahliannya melalui penelitian ilmiah dengan pendekatan inter, multi atau transdisipliner, yang disusun dalam bentuk disertasi.

Suparman (2013) dalam bukunya yang berjudul Aplikasi Komputer dalam Penyusunan Karya Ilmiah membahas tentang skripsi, tesis, dan disertasi secara rinci berdasarkan berbagai sumber. Karya ilmiah yang merupakan karya formal, dan dibimbing, serta memenuhi persyaratan dalam bentuk skripsi, tesis, dan disertasi. Banyak di jumpai bahwa skripsi mempunyai kualitas seperti tesis, bahkan seperti disertasi. Tidak jarang pula dijumpai hal sebaliknya, disertasi seperti tesis, bahkan sama dengan skripsi.

Perbedaan yang dapat di uraikan antara skripsi, tesis, dan disertasi diuraikan sebagaimana tulisan berikut ini. Perbedaan Skripsi, Tesis dan Disertasi antara lain dapat ditemukan pada sumber di http://www.infos-ripsi.com /Article/ Perbedaan-Skripsi-Tesisdan-Disertasi.html yang di retrieved pada 6 September 2012, menunjukkan bahwa ketiga jenis karya ilmiah tersebut mempunyai cirri sebagai berikut.

1. Skripsi menjawab apa (kajian),

2. Tesis menjawab apa dan mengapa (pengembangan), dan

3. Disertasi itu menjawab apa, mengapa dan bagaimana (menemukan atau menciptakan).

Contoh tentang penelitian daun katuk dalam menurunkan kolesterol telur.

1. Skripsi hanya menjawab pertanyaan apakah daun katuk menurunkan kolesterol telur?

2. Tesis itu menjawab dua pertanyaan, yaitu a) apakah daun katuk menurunkan kolesterol telur dan; b) mengapa daun katuk menurunkan kolesterol.

3. Disertasi menjawab tiga pertanyaan, yaitu: a) apakah daun katuk menurunkan kolesterol telur?; b) mengapa daun katuk menurunkan kolesterol telur? dan; c) bagaimana cara (mekanisme) daun katuk menurunkan kolesterol telur?

Contoh lain tentang pemanfaatan "Sumur Wakaf Suparman" di Tempuran Gadog bagi masyarakat sekitar dan para pengunjung ritualan. Pada awalnya pembangunan sumur ini ditentang, karena dianggap sangat aneh membuat sumur di pinggir kali dan tidak jauh 
dari lokasi sumur ada mata air yang dapat diakses oleh masyarakat. Kemudian setelah selesai pembuatan sumur wakaf tersebut, dan ternyata sumur itu mempunyai sumber air yang bermutu sangat bagus. Bahkan dapat diminum secara langsung dan dipercayai sebagai obat.

1. Skripsi hanya menjawab pertanyaan apakah "Sumur Wakaf Suparman" bermanfaat bagi masyarakat sekitar dan para pengunjung ritualan?

2. Tesis itu menjawab dua pertanyaan, yaitu a) apakah "Sumur Wakaf Suparman" bermanfaat bagi masyarakat sekitar dan para pengunjung ritualan? dan; b) mengapa "Sumur Wakaf Suparman" bermanfaat bagi masyarakat sekitar dan para pengunjung ritualan?

3. Disertasi menjawab tiga pertanyaan, yaitu: a) apakah "Sumur Wakaf Suparman" bermanfaat bagi masyarakat sekitar dan para pengunjung ritualan? dan; b) mengapa "Sumur Wakaf Suparman" bermanfaat bagi masyarakat sekitar dan para pengunjung ritualan? dan; c) bagaimana "Sumur Wakaf Suparman" bermanfaat bagi masyarakat sekitar dan para pengunjung ritualan?

Berikut dikemukakan aspek-aspek yang dapat membedakan skripsi, tesis, dan disertasi, terutama yang merupakan hasil penelitian kuantitatif. Dalam artikel bersumber dari http:// www. mediaskripsi. com/ beda-tesis-dan-disertasi. php menyebutkan bahwa secara akademik skripsi, tesis dan disertasi memiliki persamaan yaitu merupakan dokumen tertulis yang merupakan tugas akhir para mahasiswa, mengikuti kaidah penulisan yang baku dan sistematis, dan menggunakan metode ilmiah yang dapat dipertanggung jawabkan di depan dosen pembimbing dan penguji. Skripsi adalah Tugas akhir jenjang sarjana (S1), Tesis adalah Tugas akhir jenjang Magister (S2) sedangkan Disertasi (S3) merupakan Tugas akhir jenjang Doktor (S3, jenjang tertinggi akademik). Skripsi adalah tugas akhir calon sarjana dengan level sebagai peneliti pemula atau pembelajaran menjadi peneliti, dimana bobot penelitian dan ketajaman analisis paling rendah dibandingkan dengan Tesis atau Disertasi.

Namun demikian banyak pula mahasiswa yang belum mengerti perbedaan di antara ketiganya. Pada skripsi, kajian deskriptif atau paparan lebih dominan dibandingkan dengan kajian analitis. Disamping itu pada skripsi jumlah rumusan masalah biasanya sekitar 1 atau 2 rumusan masalah, sedangkan tesis biasanya minimal 3 rumusan masalah. Kemudian untuk doktor lebih dari 3 rumusan masalah dengan bobot ilmiah yang paling tinggi dibandingkan yang lain (Lihat Tabel.1).

\section{Menentukan Judul}

Peneliti pada saat menentukan judul, bagaikan seorang calon ayah atau calon ibu baik secara individual maupun secara bersama sama akan memberikan nama anaknya yang masih dalam kandungan. Banyak buku terbit yang berjudul memberikan nama bayi yang akan lahir, yang diwarnai islam, protestan, katolik, dll. Terkadang begitu mudahnya, atau begitu sulitnya, dan tidak pernah didapatkan. Saking sulitnya banyak pasangan yang pergi ke Kiai, pendeta, pastur, soho, bante, bahkan ke paranormal atau dukun sekalipun. Baru mendapatkan nama calon anaknya yang akan lahir. Situasi ini analog, sama halnya dengan peneliti dalam menentukan judulnya. 
Tabel 1 Perbedaan Umum antara Skripsi, Tesis dan Disertasi

\begin{tabular}{|c|c|c|c|c|}
\hline \multirow{2}{*}{ No } & Aspek & Skripsi & Tesis & Disertasi \\
\hline & Jenjang & S1 & S2 & S3 (tertinggi) \\
\hline 1 & $\begin{array}{c}\text { Rancangan PP- } \\
\text { SNPT } 2013\end{array}$ & $\begin{array}{l}\text { Strata satu dituntut dapat } \\
\text { melaporkan kajian ilmu } \\
\text { pengeahuan atau teknologi }\end{array}$ & $\begin{array}{l}\text { Strata dua dituntut } \\
\text { mengembangkan ilmu } \\
\text { pengetahuan dan atau } \\
\text { teknologi }\end{array}$ & $\begin{array}{l}\text { Strata tiga dituntut } \\
\text { menemukan atau } \\
\text { menciptakan ilmu } \\
\text { pengetahuan atau teknlogi. }\end{array}$ \\
\hline 2 & Permasalahan & $\begin{array}{l}\text { Dapat diangkat dari } \\
\text { pengalaman empirik, tidak } \\
\text { mendalam }\end{array}$ & $\begin{array}{l}\text { Diangkat dari pengalaman } \\
\text { empirik, dan teoritik, } \\
\text { bersifat mendalam }\end{array}$ & $\begin{array}{l}\text { Diangkat dari kajian teoritik } \\
\text { yang didukung fakta } \\
\text { empirik, bersifat sangat } \\
\text { mendalam }\end{array}$ \\
\hline 3 & Kemandirian penulis & $\begin{array}{l}60 \% \text { peran penulis, } 40 \% \\
\text { pembimbing }\end{array}$ & $\begin{array}{l}80 \% \text { peran penulis, } 20 \% \\
\text { pembimbing }\end{array}$ & $\begin{array}{l}90 \% \text { peran penulis, } 10 \% \\
\text { pembimbing }\end{array}$ \\
\hline 4 & Bobot Ilmiah & Rendah - sedang & $\begin{array}{l}\text { Sedang - tinggi. } \\
\text { Pendalaman / } \\
\text { pengembangan terhadap } \\
\text { teori dan penelitian yang } \\
\text { ada }\end{array}$ & $\begin{array}{l}\text { Tinggi, Tertinggi dibidang } \\
\text { akademik. Diwajibkan } \\
\text { mencari terobosan dan teori } \\
\text { baru dalam bidang ilmu } \\
\text { pengetahuan }\end{array}$ \\
\hline 5 & Pemaparan & Dominan deskriptif & Deskriptif dan Analitis & Dominan analitis \\
\hline 6 & Model Analisis & Rendah-sedang & Sedang - tinggi & Tinggi \\
\hline 7 & $\begin{array}{l}\text { Jumlah rumusan } \\
\text { masalah }\end{array}$ & Sekitar 1-2 & Minimal 3 & Lebih dari 3 \\
\hline 8 & Metode / Uji statistik & $\begin{array}{l}\text { Biasanya memakai uji } \\
\text { Kualitatif / Uji deskriptif, } \mathrm{Uji}_{\mathrm{ji}} \\
\text { statistik parametrik (uji } 1 \\
\text { pihak, 2 pihak), atau } \\
\text { Statistik non parametrik } \\
\text { (test binomial, Chi kuadrat, } \\
\text { run test), uji hipotesis } \\
\text { komparatif, uji hipotesis } \\
\text { asosiatif, Korelasi, Regresi, } \\
\text { Uji beda, Uji Chi Square, d11 }\end{array}$ & $\begin{array}{l}\text { Biasanya memakai uji } \\
\text { Kualitatif lanjut / regresi } \\
\text { ganda, atau korelasi ganda, } \\
\text { mulitivariate, multivariate } \\
\text { lanjutan (regresi dummy, } \\
\text { data panel, persamaan } \\
\text { simultan, regresi logistic, } \\
\text { Log linier analisis, } \\
\text { ekonometrika static \& } \\
\text { dinamik, time series } \\
\text { ekonometrik) Path analysis, } \\
\text { SEM }\end{array}$ & $\begin{array}{l}\text { Sama dengan tesis dengan } \\
\text { metode lebih kompleks, } \\
\text { berbobot yang bertujuan } \\
\text { mencari terobosan dan teori } \\
\text { baru dalam bidang ilmu } \\
\text { pengetahuan }\end{array}$ \\
\hline 9 & $\begin{array}{l}\text { Jenjang Pembimbing } \\
\text { / Penguji }\end{array}$ & Minimal Magister & $\begin{array}{l}\text { Minimal Doktor dan } \\
\text { Magister yang } \\
\text { berpengalaman }\end{array}$ & $\begin{array}{l}\text { Minimal Profes or dan } \\
\text { Doktor yang } \\
\text { berpengalaman }\end{array}$ \\
\hline 10 & $\begin{array}{l}\text { Orisinalitas } \\
\text { penelitian }\end{array}$ & $\begin{array}{l}\text { Bisa replika penelitian orang } \\
\text { lain, tempat kasus berbeda }\end{array}$ & Mengutamakan orisinalitas & Harus orisinil \\
\hline 11 & $\begin{array}{l}\text { Penemuan hal-hal } \\
\text { yang baru }\end{array}$ & Tidak harus & Diutamakan & Diharuskan \\
\hline 12 & $\begin{array}{l}\text { Publikasi hasil } \\
\text { penelitian }\end{array}$ & $\begin{array}{l}\text { Kampus Internal dan } \\
\text { disarankan nasional }\end{array}$ & Minimal Nasional & Nasional dan Internasional \\
\hline 13 & $\begin{array}{l}\text { Jumlah rujukan / } \\
\text { daftar pustaka }\end{array}$ & Minimal 20 & Minimal 40 & Minimal 60 \\
\hline 14 & $\begin{array}{l}\text { Metode / Program } \\
\text { statistik yang biasa } \\
\text { digunakan }\end{array}$ & $\begin{array}{l}\text { Kualitatif / Manual, Excel, } \\
\text { SPSS d11 }\end{array}$ & $\begin{array}{l}\text { Kualitatif lanjut / SPSS, } \\
\text { Eview, Lisrel, Amos dll }\end{array}$ & $\begin{array}{l}\text { Kualitatif lanjut / SPSS, } \\
\text { Eview, Lisrel, Amos dll }\end{array}$ \\
\hline
\end{tabular}

Sumber: Agung Wahyudi Biantoro, Metode Penelitian Ekonomi Islam, 2009, diolah dari http://wsetiabudi .wordpress.com 
Peneliti dalam menentukan judul sangat berhubungan erat dengan topik dan tema nya. Topik berasal dari bahasa Yunani "topoi" yang berarti tempat atau pokok pembicaraan sebagai landasan laporan suatu artikel. Kemudian tema berasal dari bahasa Yunani "thithenai", berarti sesuatu yang telah diuraikan dan ditempatkan. Tema merupakan amanat utama yang disampaikan oleh peneliti melalui laporannya. Jadi tema adalah pokok pikiran yang mendasari karangan yang akan disusun. Dalam tulis menulis, tema adalah pokok bahasan yang akan disusun menjadi laporan. Tema ini yang akan menentukan arah tulisan atau tujuan karya ilmiah itu. Menentukan tema berarti menentukan apa masalah sebenarmya yang akan ditulis atau diuraikan oleh peneliti.

Sebelum menentukan judul peneliti menyusun rumusan masalah secara spesifik, jelas, dan meyakinkan. Masalah sendiri merupakan gap antara apa yang seharusnya dan apa yang terjadi, teori dan praktek, aturan dan pelaksanaan, rencana dan pelaksanaan, pengalaman lampau dan sekarang. Penelitian yang baik, mempunyai pokok permasalahan yang baik dan dirumuskan dalam silogisme yang benar, tidak goyah pada permasalahan yang muncul belakangan, walaupun dirasakan sangat menarik. Judul yang baik mencerminkan rumusan masalah yang akan dicari jawabannya, subyek penelitian, wilayah penelitian, waktu penelitian, dan alat analisis/software yang digunakan. Judul merupakan miniatur isi bahasan. Judul diusahakan tidak lebih dari tiga baris, tetapi cukup menggambarkan isi bahasan. Dalam bentuk pernyataan singkat (max. 20 kata), padat, jelas, mencerminkan variabel dan materi yang diteliti. Judul penelitian dapat merupakan hasil perumusan hipotesis yang ada dalam penelitian.

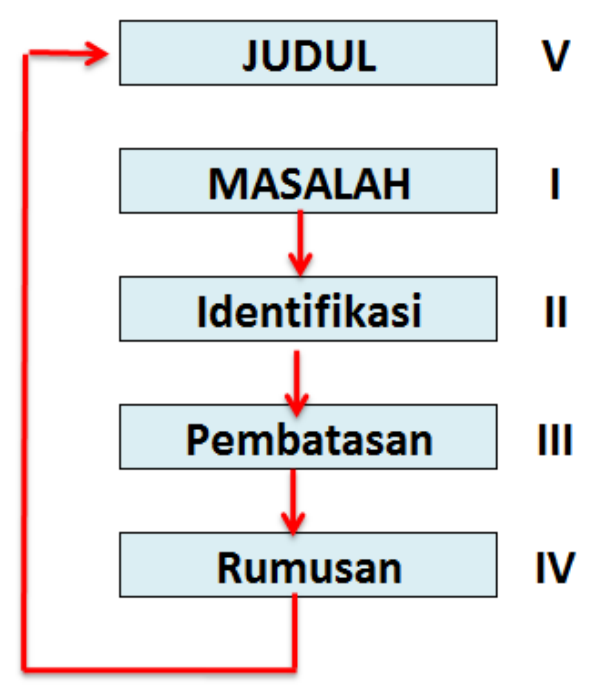

Gambar 1. Proses penentuan judul

Judul penelitian merupakan gerbang bagi pembaca sebuah laporan penelitian. Judul penelitian juga dapat menggambarkan interaksi antar dua variabel atau lebih, baik membedakan (pengaruh) atau menghubungkan (keterkaitan). Judul mempunyai unsur yang terdiri dari variabel yang diteliti ialah variabel dependen dan independen, tempat dan tahun penelitian. Judul harus dapat menggambarkan "isi" dari apa yang sedang diteliti, menggambarkan hubungan variabel dependen dengan variabel independent, mempunyai daya tarik, sehingga orang mau membaca keseluruhan isinya. Contoh: Faktor-faktor yang mempengaruhi keberhasilan belajar mahasiswa Program Studi XYZ pada Perguruan Tinggi KLM, di Jakarta tahun 2013. 
Tabel 2 Daftar Kata Awal Judul Skripsi, Tesis, dan Disertasi

\begin{tabular}{|r|l|}
\hline \multicolumn{1}{c|}{ No } & Kata-kata \\
\hline 1 & Aktivitas ... \\
\hline 2 & Aplikasi ... \\
\hline 3 & Bahan aktif ... \\
\hline 4 & Dampak ... \\
\hline 5 & Daur ulang ... \\
\hline 6 & Fabrikasi ... \\
\hline 7 & Formulasi ... \\
\hline 8 & Gen penyandi ... \\
\hline 9 & Mekanisme ... \\
\hline 10 & Modifikasi ... \\
\hline 11 & Paket teknologi ... \\
\hline 12 & Partisipasi masy. Dalam ... \\
\hline 13 & Pemanfaatan ... \\
\hline 14 & Pencegahan ... \\
\hline 15 & Pengaruh ... \\
\hline 16 & Pengembangan teknik, model \\
\hline
\end{tabular}

\begin{tabular}{|l|l|}
\hline No & Kata-kata \\
\hline 17 & Penyusunan ... \\
\hline 18 & Perakitan ... \\
\hline 19 & Potensi ... \\
\hline 20 & Prediksi ... \\
\hline 21 & Produksi antibodi ... \\
\hline 22 & Rehabilitas, Konservasi ... \\
\hline 23 & Rekayasa ... \\
\hline 24 & Remediasi ... \\
\hline 25 & Revitalisasi ... \\
\hline 26 & Sintesis ... \\
\hline 27 & Standaridisasi ... \\
\hline 28 & Strategi ... \\
\hline 29 & Transformasi ... \\
\hline 30 & Upaya ... \\
\hline 31 & Transformasi ... \\
\hline 32 & Dan lain sebagainya, \\
\hline
\end{tabular}

Selanjutnya perlu diperhatikan daftar variabel dibawah ini dalam menyusun judul penelitian.

Variabel Terikat

1. Hasil Belajar

2. Prestasi Belajar

3. Hasil Nilai UAN

4. Kemmuan membaca, menuis, mendengrkan

5. Pretes

6. Postes

7. Nilai UTS

8. Nlai UAS

9. dll

Variabel Eksperimen

1. Metode Pembelajaran \{Diskusi, Pemecahan Masalah, Ceramah, Inquiry\},

2. Model Pembelajar \{Jigsaw, TGT, STAD, TAI\},

3. Media \{ICT, Pesona, Model, Gambar\},

4. Pendekatan \{Kontekstual, Konseptual, Deduktif, Induktif, Siswa Oriented, Guru Oriented, Pemecahan masalah\},

5. Strategi pembeajaran

6. dll

Variabel Atribute (Menempel pada diri siswa)

1. Motivasi

2. Minat

3. Kebiasaan

4. Disiplin

5. Konsep diri

6. Percaya diri 
7. Efikasi

8. Gaya belajar \{kognitif, visual, kenestetik\}

9. Gaya kognitf \{dep vs indep. Ekstropet vs intropet

10. Karakter \{melangkoli, sanguinis, flegmatis, dan koleris\}

11. IQ \{ ada 8 kategori\}

12. SQ

13. EQ

14. SosQ

15. Persepsi atas ....

16. Dll..

\section{METODE}

Penelitian ini menggunakan metode deskriptif statistik dengan mengolah data sampel 1052 judul tesis. Data diolah dengan menggunakan program excel untuk mengelompokkan modus kata yang muncul pada judul tesis yang diteliti. Tabel deskriptif ditampilkan sedemikian rupa sehingga informasi penting dapat dianalisis. Analisis table deskritif ini merupakan temuan dan simpulan.

Selanjutnya dilakukan analisis isi dengan membaca modus keterkaitan, dan kata kunci penting yang menggambarkan kandungan dari tesis yang ada. Kemudian mengambil sampel 15 tesis lengkap menurut variasi yang ada secara proporsional. Selanjutnya dikaji dianalisis isi untuk mengetahui sistim penulisan dan sumber kutipan (quotations) yang dipergunakan. Kata kunci dipergunakan untuk analisis, seperti kata awal judul antara lain "Pengaruh", "Analisis", "Hubungan", "Aspek". Variabel dependen denga kata "Hasil Belajar", "Prestasi Belajar", "Kemampuan". Variabel independen "Motivasi", "Minat", "Sikap", "Pengeahuan", "Disiplin", "Gaya Belajar", "Model Pembelajaran:, "Media Pembelajaran", "Komunikasi Sosial, kelas, personal, interpersonal, dll", "Persepsi atas...", dll. Data diolah dengan menggunakan exel MSOffice dengan fasilitas Find \& Selection. Kata kunci dimasukkan dan di klik find all. Akan didapatkan total judul yang mengandung kata kunci tersebut, dan juga keluar lembar exel yeng memuat kata kata itu.

Metode analisis yang dipergunakan adalah analisis deskriptif dan analisis isi dari judul judul tersebut menurut kata kata kunci yang disebutkan diatas.

\section{HASIL}

Berikut ini analisis hasil kajian tentang judul tesis dan kajian isi 15 tesis yang dipilih dari 1052 judul tesis yang didata. Kajian judul dikaji kecenderungan penggunaan kata kata, baik kata kata yang dipergunakan pada awal kalimat judul, kata kata sebagai variabel bebas, dan kata kata sebagai variabel terikat. Kemudian isi tesis dikaji kandungan nya baik penulisan, cara pekutipan, dan ain sejensnya.

\section{Judul}

Kata awal. Judul tesis menunjukkan bahwa dominasi penggunaan kata awal kalimat Pengaruh ada 788 judul, atau 74.90 persen, kata awal Analisis ada 38 judul atau 3.61 persen, kata awal Hubungan ada 26 judul atau 2.47 persen, kata Aspek ada 21 judul atau 2.00 persen. Secara umum juga dapat dilihat secara visual sebagaimana pada Gambar.1 dibawah ini. Kata awal yang digunakan pada tesis pascasarjana perguruan tinggi ini adalah kata pengaruh, the effect, analysis, aspek, dan hubungan. Secara umum pada program studi MIPA, dan IPS. Namun Bahasa Inggris dan Bahasa Indonesia juga dominan. Kata the effect sangat dominan pada program studi Bahasa Inggris. 
Variabel Dependen. Berdasarkan variabel dependen umumnya ada dua, ialah hasil belajar dan prestasi belajar. Variabel dependen atau yang dipengaruhi dengan pasangan kata Hasil Belajar ada 247 judul atau 23,48 persen. Pasangan kata ini umumnya dipergunakan untuk tesis yang dilakukan dengan eksperimen, atau sejenisya. Kemudian ada variabel dependen yang dominan dengan pasangan kata Prestasi Belajar ada 205 judul, atau 19,49 persen. Pasangan kata ini umumnya dipergunakan untuk tesis yang datanya didapatkan berdasarkan survey.

Variabel independen. Variabel independen biasanya kombinasi dari variabel dengan kata kata sebagai berikut. Kata pembelajaran ada 300 judul atau 28.52 persen, kata ini biasanya tidak berdiri sendiri melainkan pasangan kata dengan model atau kata metode atau media, artinya variabel independen dalam eksperimen dengan rangkaian kata model pembelajaran, metode embelajaran, atau media pembelajaran. Kata model ada 165 judul, atau 15.68 persen. Kemudian kata metode ada 118 judul, atau 11.22 persen. Selanjutnya kata media ada 114 judul, atau 10.84 persen. Variabel independen lainnya berulang antara 25 persen sampai dengan 0,7 persen. Kata yang paling banyak berulang adalah motivasi. Motivasi ini ada pasangan kata antara lain motivasi belajar, motivasi berprestasi, motivasi kerja, dan lainnya yang sejenis. Kata motivasi menunjukkan angka 268 judul, atau 25.48 persen. Kemudian kata kemampuan ada 210 judul, atau 19.96 persen. Kemampuan ini juga mempunyai pasangan kata seperti kemampuan awal, kemampuan berpikir kritis, kemampuan berkomunkasi matematik, kemampuan interpersonal, kemampuan memahami isi wacana, dan lainnya yang sejenis. Berikutnya adalah kata minat yang juga mempunyai pasangan kata seperti minat belajar, minat membaca, dan lainnya yang sejenis. Kata minat dijumpai ada 183 judul, atau 17.40 persen. Kata persepsi atas hal tertentu ada 110 judul, atau 0.46 persen. Kata kecerdasan ada 73 judul, atau 6.94 persen. Kata ini juga mempunyai pasangan kata seperti kecerdasan emosional, kecerdasan intelektual, kecerdasan social, dan lainnya yang sejenis. Gaya Belajar ada 52 judul, atau 4.94 persen. Kompetensi ada 43 judul, atau 4.09 persen. Kata kompetensi mempunyai pasangan kata kompetensi pedagogik guru, kompetensi social, kompetensi professional, dan lainnya yang sejenis. Konsep diri ada 38 judul, atau 3.61 persen. Konsep diri merupakan satu kesatuan yang secara langsung merupakan variabel bebas. Disiplin ada 37 judul, atau 3.52 persen. Disiplin juga merupakan satu kata yang secara langsung merupakan variabel bebas. Sikap ada 32 judul, atau 3.04 persen. Sikap mempunyai pasangan kata sikap terhadap sesuatu. Misalnya Sikap Siswa Terhadap Bahasa Indonesia, Sikap Ilmiah Siswa, dan lain nya yang sejenis. Kebiasaan ada 19 judul, atau 1.81 persen. kesalahan ada 10 judul, atau 0.95 persen. Kesalahan mempunyai pasangan kata seperti kesalahan morfologi, kesalahan sintaksis, kesalahan gramatikal dan lain sejenisnya. Kesalahan Visual ada 7 judul, atau 0.67 persen. 
Tabel 3 Kata kata dalam Judul Tesis menurut Abjad dan menurut jumh yang tampil

\begin{tabular}{|c|l|r|r|}
\hline \multicolumn{4}{|c|}{ Urut Abjad } \\
\hline No & Kata-kata & Jumlah & Persentase \\
\hline 1 & Analisis & 38 & 3.61 \\
\hline 2 & Aspek & 21 & 2.00 \\
\hline 3 & Disiplin & 37 & 3.52 \\
\hline 4 & Error / Kesalahan & 10 & 0.95 \\
\hline 5 & Gaya Belajar & 52 & 4.94 \\
\hline 6 & Hasil Belajar & 247 & 23.48 \\
\hline 7 & Hubungan & 26 & 2.47 \\
\hline 8 & Kebiasaan & 19 & 1.81 \\
\hline 9 & Kecerdasan & 73 & 6.94 \\
\hline 10 & Kemampuan & 210 & 19.96 \\
\hline 11 & Kompetensi & 43 & 4.09 \\
\hline 12 & Konsep diri & 38 & 3.61 \\
\hline 13 & Media & 114 & 10.84 \\
\hline 14 & Metode & 118 & 11.22 \\
\hline 15 & Minat & 183 & 17.40 \\
\hline 16 & Model & 165 & 15.68 \\
\hline 17 & Motivasi & 268 & 25.48 \\
\hline 18 & Pembelajaran & 300 & 28.52 \\
\hline 19 & Pengaruh & 788 & 74.90 \\
\hline 20 & Persepsi atas & 110 & 10.46 \\
\hline 21 & Prestasi Belajar & 205 & 19.49 \\
\hline 22 & Sikap & 32 & 3.04 \\
\hline 23 & Visual & 7 & 0.67 \\
\hline
\end{tabular}

\begin{tabular}{|r|l|r|r|}
\hline \multicolumn{4}{|c|}{ Urut Jumlah } \\
\hline No & Kata-kata & Jumlah & Persentase \\
\hline 1 & Pengaruh & 788 & 74.90 \\
\hline 2 & Pembelajaran & 300 & 28.52 \\
\hline 3 & Motivasi & 268 & 25.48 \\
\hline 4 & Hasil Belajar & 247 & 23.48 \\
\hline 5 & Kemampuan & 210 & 19.96 \\
\hline 6 & Prestasi Belajar & 205 & 19.49 \\
\hline 7 & Minat & 183 & 17.40 \\
\hline 8 & Model & 165 & 15.68 \\
\hline 9 & Metode & 118 & 11.22 \\
\hline 10 & Media & 114 & 10.84 \\
\hline 11 & Persepsi atas & 110 & 10.46 \\
\hline 12 & Kecerdasan & 73 & 6.94 \\
\hline 13 & Gaya Belajar & 52 & 4.94 \\
\hline 14 & Kompetensi & 43 & 4.09 \\
\hline 15 & Analisis & 38 & 3.61 \\
\hline 16 & Konsep diri & 38 & 3.61 \\
\hline 17 & Disiplin & 37 & 3.52 \\
\hline 18 & Sikap & 32 & 3.04 \\
\hline 19 & Hubungan & 26 & 2.47 \\
\hline 20 & Aspek & 21 & 2.00 \\
\hline 21 & Kebiasaan & 19 & 1.81 \\
\hline 22 & Error / Kesalahan & 10 & 0.95 \\
\hline 23 & Visual & 7 & 0.67 \\
\hline & & & \\
\hline
\end{tabular}

Sumber : Diolah dari daftar judul Tesis Unindra suatu semester genap dan ganjil tahun 2011/2012

Dari keseluruhan sampel sebanyak 1052 judul tesis menunjukkan bahwa Program studi Bahasa Indonesia sebanyak 148 judul atau 14,06 persen; Program studi Bahasa Inggris ada 248 judul atau 23,55 persen; Program studi IPS ada 290 judul atau 27,54 pesen; dan Program studi MIPA ada 366 judul, atau 34,76 persen.

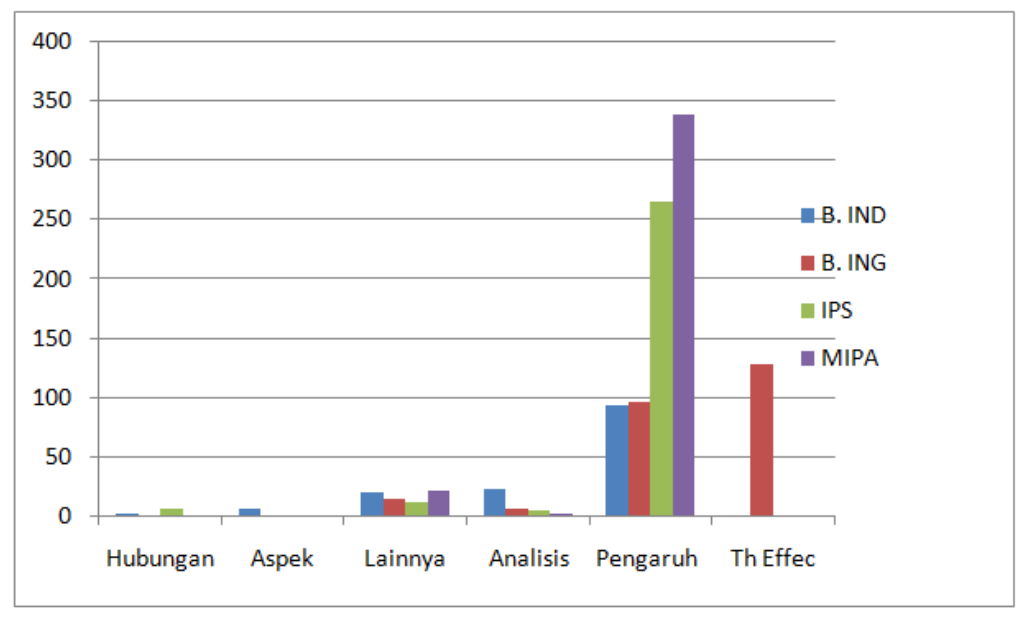

Gambar 1 Distribusi judul tesis menurut Program Studi dan Penggunaan Kata Kata Awal 


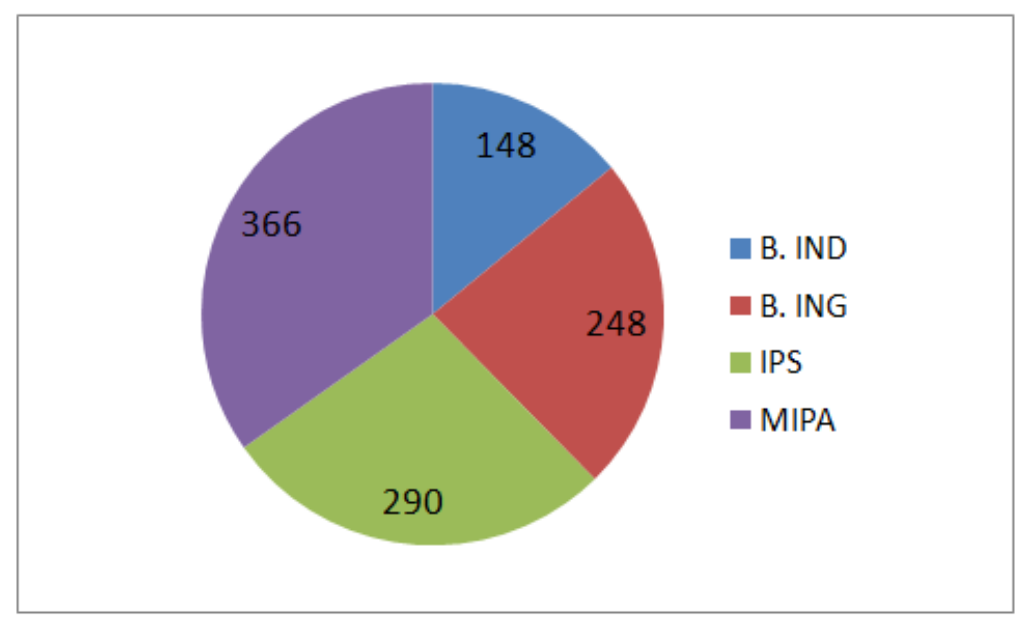

Gambar 2 Distribusi Judul Tesis menurut Program Studi

Tabel 4 Kata kata Awal Kalimat dalam Judul Tesis

\begin{tabular}{|l|r|r|r|r|r|}
\hline \multirow{2}{*}{ Kata kata } & \multicolumn{4}{|c|}{ PRODI } & \multirow{2}{*}{$\begin{array}{c}\text { Grand } \\
\text { Total }\end{array}$} \\
\cline { 2 - 5 } & B. IND & B. ING & \multicolumn{1}{c|}{ IPS } & MIPA & \multicolumn{1}{c|}{ IN } \\
\hline Analisis & 2.19 & 0.67 & 0.48 & 0.29 & 3.61 \\
\hline Aspek & 0.67 & - & - & - & 0.67 \\
\hline Hubungan & 0.29 & 0.10 & 0.67 & 0.19 & 1.24 \\
\hline Lainnya & 2.00 & 1.43 & 1.14 & 2.09 & 6.65 \\
\hline Pengaruh & 8.94 & 9.22 & 25.29 & 32.22 & 75.67 \\
\hline Th Effec & - & 12.17 & - & - & 12.17 \\
\hline Grand Total & 14.07 & 23.57 & 27.57 & 34.79 & 100.00 \\
\hline
\end{tabular}

Tabel 5 Kata kata Awal Kalimat dalam Judul Tesis menurut Prodi tertentu

\begin{tabular}{|l|r|r|r|r|r|}
\hline \multirow{2}{*}{ Kata kata } & \multicolumn{4}{|c|}{ PRODI } & \multirow{2}{*}{$\begin{array}{c}\text { Grand } \\
\text { Total }\end{array}$} \\
\cline { 2 - 5 } & B. IND & B. ING & \multicolumn{1}{c|}{ IPS } & \multicolumn{1}{c|}{ MIPA } & \multicolumn{1}{c|}{ Tol } \\
\hline Analisis & 15.54 & 2.82 & 1.72 & 0.82 & 3.61 \\
\hline Aspek & 4.73 & - & - & - & 0.67 \\
\hline Hubungan & 2.03 & 0.40 & 2.41 & 0.55 & 1.24 \\
\hline Lainnya & 14.19 & 6.05 & 4.14 & 6.01 & 6.65 \\
\hline Pengaruh & 63.51 & 39.11 & 91.72 & 92.62 & 75.67 \\
\hline Th Effec & - & 51.61 & - & - & 12.17 \\
\hline Grand Total & 100.00 & 100.00 & 100.00 & 100.00 & 100.00 \\
\hline
\end{tabular}




\section{Kajian Isi}

Kajian isi dengan mengambil 15 sampel tesis lengkap dengan judul yang berbeda. Perbedaan judul tesis lengkap ini dimaksudkan untuk mendapatkan gambaran tentang isi. Penelaahan di fokuskan kepada teknik penulisan kutipan (citation) apakah dari sumber asli atau turunan dari kutipan penulis sebelumnya, plagiat (plagiarism), pengulangan variabel dan instrument, teknik penulisan judul table dan judul gambar, penampilan secara umum.

Kutipan atau Citation. Kutipan atau citation yang dijumpai pada tesis tesis ini menunjukkan adanya kehomoginan, ialah secara umum tesis disusun berdasakan sumber tesis atau sumber lain yang sejenis yang sebelumnya sudah dituliskan. Umumnya tesis tesis tersebut dijumpai di perpustakaan atau melalui kakak kelas yang sudah lulus. Sehingga kemiripan, bahkan pengulangan kalimat sering dijumpai, hal ini dalam bahasa harian disebut sebagai penyakit turunan dalam penulisan karya ilmiah, termasuk skripsi, tesis, dan disertasi. Selanjutnya yang banyak dijumpai lagi adalah pada tesis baru menuliskan hal sebagai berikut.

Howodi menyatakan bahwa gaya belajar dibedakan menjadi tiga yaitu visual, auditory, dan kinestetic (Reni Akbar Howodi, 2009: 1)

Nampaknya lupa menyebutkan sumber tersebut (Howodi) yang harus dituliskan di daftar pustaka. Bahkan dijumpai beberapa yang juga lupa menyebutkan sumber kutipan tersebut pada daftar pustaka untuk tesis, atau disertasi, atau makalah pada daftar pustaanya. Kejadian diatas yang paling tinggi dijumpai, yang kemudian secara kasar biasa disebut plagiat. Plagiat merupakan kutipan yang dituliskan baik secara apa adanya atau secara tersirat tanpa menyebutkan sumbernya. Dari 15 sampel menunjukkan 12 diantaranya melakukan kesalahan sebagaimana diatas yang mungkin dikategorikan setengah plagiat.

Pengulangan variabel dan instrument. Sebagamana dijelaskan pada bagian kuantitatif diatas yang ditunjukkan pada table table analisis menunjukkan bahwa pengulangan kata kerja yang dipergunakan pada judul sangat tinggi, utamanya kata kerja pengaruh, analisis, dan lainnya yang sejenis. Kemudian pengulangan nama variabel dependen atau terikat, umumnya tentan hasil belajar, prestasi belajar, kinerja guru, pemahaman, keterampilan. Pengulangan variabel independen juga sangat tinggi dengan kombinasi yang berbeda misalnya metode pembelajaran, pendekatan pembeajaran, model pembelajaran, minat, motivasi, gaya belajar, penuasaan, dan lainnya yang sejenis. Bahkan dijumpai juga judul yang sama persis namun penelitian pada angkatan yang berbeda, sekolah yang berbeda, bahkan tempat yang berbeda.

Penulisan tabel dan gambar. Banyak dijumpai penulisan judul table dan gambar yang bervariasi. Misalnya letak judul table mestinya di tulis diatas badan table, dituliskan secara berurutan pada seluruh tesis, atau secara urutan pada setiap bab. Selanjutnya penulisan judul gambar mestinya dibawah badan gambar. Menuliskan sumber baik table maupun gambar mestinya dituliskan dibawah badan table atau dibawah badan gambar. Pada peelitia ini menunjukkan adanya variasi penulisan yang tidak mengikuti aturan umum. Selanjutnya menuliskan kalimat judul itu sendiri tidak menggambarkan isi yang sebenarya, baik table frekwensi atau distribusi, table, table satu arah, table dua arah, table dengan harga mutlak atau persentase tertentu atau umum. Selanjutnya table statistic seperti table statistik deskriptif menurut jenis statistic yang diperlukan, table koefisien regresi, table uji normalitas, tabel uji linearitas, table heteroskedastisitas, table uji otokorelasi, table anova, dll yang diperlukan. Peneliti banyak dijumpai kesalahan kalimat judul yang tidak sesuai dengan kaidah yang ada. Demikian juga penulisan gambar atau 
diagram yang masih banyak keliru. Sama halnya dalam penulisan sumber yang juga masih dijumpai banyak kesalahan.

Penampilan secara umum. Jadi penampilan secara umum sudah menunjukkan yang benar, namun masih banyak dijumpai juga kekeliruan yang terjadi. Bahkan banyak dijumpai variasi format penyajian table, penulisan judul, penulisan sumber yang berbeda pada tesis yag sama. Hal ini karena kekeliruan atau kesalahan turunan. Peneliti meniru tesis tertentu pada table tertentu, dan di pihak lain meniru tesis yang berbeda untuk menuliskan table yang lain. Selajutnya setelah dilakukan wawancara secara mendalam kepada beberapa alumni menyatakan bahwa kebanyakan meniri tesis yang sudah lulus, kemudian tidak membeca secara benar buku panduan penulisan tesis yang ada. Kemudian banyak peneliti melakukan fetakompli kepada pembimbingnya untuk mendapatkan tanda tanagan persetujuan layak diujikan.

\section{PENUTUP}

\section{Kesimpulan}

Pengulangan variabel dependen maupun variabel independen sangat tinggi, namun dengan berbagai kombinasi, dan pada sekolah yang berbeda, waktu yang berbeda. Hal ini tidak dilarang secara aturan penulisan tesis. Pengulangan variabel dan instrument juga masih banyak dijumpai, utamanya pada instrument, amun dilakukan uji validitas dan reliabilitas secara benar. Sehingga instrument akhir dijumpai berbeda jumlah butir nya.

Kutipan yang ada masih banyak dijumpi kutipan secara utuh dari sumber, masih sedikit kutipan yang dibuat dengan kalimat kalimat sendiri. Plagiat minor masih banyak ditemukan, karena pada umumnya bersumber pada tesis terdahulu.

Penulisan tabel dan gambar masih banyak kekurangannya, belum mengikuti aturan yang benar. Penampilan secara umum masih dijumpai yang dikarenakan adanya kesalahan turunan.

\section{Saran}

Saran yang dapat disampaikan atas penelitian ini adalah sebagai berikut.

Perlu ada bank judul yang terdiri dari judul yang pernah dipergunakan di perguruan tinggi XYZ tersebut, dari perguruan tinggi sejenis, sumber internet, perpustakaan nasional maupun internasional, library congress, dan berbagai sumber yang sejenis.

Workshop peningkatan mutu tesis yang diikuti para pembimbing dan alumni. Mediskusikan tentang judul dalam penelitian tesis yang ada dan penyempurnaan nya.

Kerjasama dengan pascasarjana sejenis dalam rangka peningkatan mutu karya ilmiah khususnya tesis secara nasional maupun secara internasional.

\section{DAFTAR PUSTAKA}

Agung Wahyudi Biantoro, A.W. 2009. Metode Penelitian Ekonomi Islam. Diunduh 20 Oktober, 2012 dari http://wsetiabudi .wordpress.com

Peraturan Pemerintah. 2013. Peraturan Pemerintah tentang Pendidikan dan Kebudayaan Republik Indonesia Tentang Standar Nasional Pendidikan Tinggi (SNPT) Kementerian Pendidikan dan Kebudayaan Direktorat Jenderal Pendidikan Tinggi Dan Badan Standar Nasional Pendidikan 2013. Jakarta: Depdiknas.

Unknown. (2012). Perbedaan Skripsi-Tesis-Disertasi. Diunduh 6 September, 2012 dari http://www.infos-ripsi.com /Article/ Perbedaan-Skripsi-Tesis-dan-Disertasi.html.

Unknown. (2012). Beda Skripsi-Tesis-Disertasi. Diunduh 10 September, 2012 dari http:// www. mediaskripsi. com/ beda-tesis-dan-disertasi. php 


\section{LAMPIRAN Contoh Judul Tesis}

1. An Analysis of Grammatical Structures in English On Sky and real Time Text books in Relation to Krashen's Natural order Hypothesis

2. An Analysis of Grammatical Structures in English Zone and English Textbook for Senior High School Textbook on Tenth Grade Students in Relation to Krasen's Natural Order Hypothesis

3. An Error Analysis On Active And Passive Voices On Student Writing Skill In Spoof Text At Private Senior High Schools In Bogor

4. Analisis aspek sosiologis dan pisikologis dalam novel "Cinta Setengah Hati" karya Yunita Tri Damayanti dan implikasinya dalam pendidikan anak kebutuhan khusus

5. Analisis deiksis pada karya sastra (dongeng cerita rakyat Jawa Tengah) terhadap pembelajaran Bahasa Indonesia di SMK

6. Analisis Implikatur Percakapan Film Heart Dan Implikasinya Bagi Pembelajaran Bahasa Dan Sastra Indonesia Tingkat SMA

7. Analisis Kesalahan Bahasa Dan Interferensi Pada Karangan Narasi Siswa Kelas XI SMK Swasta di Bogor

8. Analisis kesalahan gramatikal dan penguasaan kosa kata terhadap penulisan pidato sumpah pemuda kelas IX SMP Bekasi

9. Analisis Kesalahan Morfologi dan Sintaksis dalam Karangan Deskriptif Bahasa Inggris Siswa MA di Kota Depok

10. Pengaruh Gaya Belajar Dan Minat Belajar Terhadap Prestasi Belajar Biologi Siswa ( Expose Facto Pada Siswa Kelas XI SMA Negeri Di Kecamatan Tapos Depok )

11. Pengaruh Metode Pembelajran dan Motivasi Belajar terhadap Hasil Belajar Siswa pada Materi Pokok Ekosistem di Kelas VII SMP SeKecamatan Penjaringan Jakarta Utara

12. Pengaruh Model Pembelajaran dan Pola Asuh Orangtua terhadap Hasil Belajar Biologi SMA di Kecamatan Cilandak

13. Pengaruh Motivasi Belajar Siswa dan Kecerdasan Interpersonal terhadap Prestasi Belajar IPS Materi Semester Ganjil Kelas VII pada SMP Swasta Kecamatan Cilandak Jakarta Selatan

14. Pengaruh motivasi dan minat terhadap hasil belajar siswa SMPN 12 Tangerang Selatan

15. Pengaruh Motivasi dan Model Pembelajaran Kooperatif dalam Peningkatan

16. Pengaruh Motivasi Kerja Dan Kecerdasaan Emosional terhadap Kinerja Guru Di Wilayah Jakarta Selatan

17. Pengaruh Partisipasi Aktif Orang Tua dan Motivasi Belajar terhadap Prestasi Belajar IPA (Survey pada Siswa Kelas VIII di Kecamatan Beji, Depok)

18. Pengaruh Peguasaan Tata Bahasa Dan Kebiasaan Membaca Siswa Terhadap Hasil Belajar Ketrampilan Membaca Teks Deskriptive Siswa SMK Swasta di Kabupaten Bogor

19. Pengaruh pembelajaran kontekstual terhadap pemahaman konsep pada materi larutan penyangga siswa kelas XI IPA SMA Kabupaten Sumedang dengan mengontrol kemampuan awal.

20. Pengaruh Pembelajaran Kooperatif Dan Penggunaan Media Pembelajaran Terhadap Hasil Belajar Ipa Terhadap Siswa Kelas VI SD Swasta Di Kecamatan Srengseng Jakarta Barat

21. Pengaruh Pemberian Motivasi Dan Penggunaan Media Pembelajaran Terhadap Hasil Pelajaran IPS Kelas VIII Tingkat SMP Di Kecamatan Tanjung Priuk

22. Pengaruh Pemberian Pekerjaan Rumah dan Model Pembelajran Berbasis ICT terhadap Hasil Belajar Matematika Siswa SMP di Kecamatan Cilandak Jakarta Selatan

23. Pengaruh Pendekatan Pembelajaran dan Konsep Diri terhadap Hasil Belajar Fisika

24. Pengaruh Penetapan Metode Pembelajran Kooperatif terhadap Kemampuan Penalaran dan Penguasaan Kosep Matematika)

25. Pengaruh Penggunaan Media Pembelajaran Berbasis TIK Dan Kedisiplinan Belajar Terhadap Hasil Belajar Biologi (Eksperimen Pada SMA Negeri Di Kecamatan Cilincing)

26. Pengaruh Penggunaan Pendekatan Pakem Dan Minat Belajar Terhadap Hasil Belajar IPA

27. Pengaruh Perhatian Orangtua dan Minat Belajar terhadap Hasil Belajar IPS Siswa SMA di Jakarta Selatan

28. Pengaruh Persepsi Dan Kepercayaan Diri Siswa Terhadap Kemampuan Berbicara Bahasa Inggris Pada Siswa Smp Swasta Di Tanah Abang Jakarta Pusat

29. Pengaruh Persepsi Siswa Pada Kemampuan Mengajar Guru Dan Motivasi Belajar Siswa Terhadap Prestasi Belajar Matematika SMP Di Jakbar

30. Pengaruh Persepsi Siswa pada Kompetensi Guru dan Minat Belajar Siswa terhadap Hasil Belajar Matematika di Kelas VIII MTs. Kecamatan Mampang Prapatan Jakarta Selatan

31. Pengaruh Rasa Percaya Diri dan Kemandirian Belajar terhadap Prestasi Belajar Matematika Siswa SMK Teknologi dan Informatika di Wilayah Jakarta Selatan

32. Pengaruh Rasa Percaya Diri Dan Minat Belajar Terhadap Prestasi Belajar Mata Pelajaran Ekonomi Di SMAN Kab. Tangerang

33. Penggaruh minat membaca dan kebiasaan membaca terhadap kemampuan membaca berita pada siswa kelas VIII SMP negri dan swasta di wilayah kecamatan

34. Peran Jepang terhadap Kemerdekaan Indonesia dan Dampaknya pada Masyarakat Indonesia Tahun 1942-1945

35. Peran Masyumi dalam Kabinet Parlementer (1950-1959)

36. Structural Analysis Of English War Poems In Finding Patriotism And Disillusion

37. Struktur Kalimat dalam Teks Wacana Iklan Produk Obat Pada Media Cetak

38. The Effects of Teaching Method and Emotional Intellegence towards Student's Speaking Skill (Study at Senior High Schools in Tangerang Kota)

39. Validity and Realiabilty analize on Language Testing Items of SMP Students In Depok

40. Validity and Realibity Analysis On the Test Items Based on Bloom's Taxonomy

41. Validity and Reliability Analysis on Summative Test Items at State Senior High Schools in East Bandung. 